\section{Inhalt}

\section{Anorganische Chemie/Inorganic Chemistry}

du Mont, W.-W., Lange, L.,

11 Eigenschaften von Tellur-Tellur-Bindun-

Karsch, H. H., Peters, K., Peters, E.-M., von Schnering, H. G.

Hetterich, W., Kisch, $\mathrm{H}$.

15 Heterogene Photokatalyse. V. - Cadmium-Zinksulfide als Katalysatoren der Photodehydrodimerisicrung von 2.5. $\mathrm{Di}$ hydrofuran

Bogdanović, B., Schlichte, K., Westeppe, U.

27 Dehalogenierungen von geminalen Dihalogencyclopropanen, s...-Dichlorcyclobutanonen und Halogenketonen mit Hilfe von Magnesiumanthracen 3 THF

Bogdanovic, B., Janke, N., Kinzelmann, H.-G., Westeppe, U.

Paetzold, P., Pelzer, C., Boese, R.

Paetzold, P., Eleftheriadis, E., Minkwitz, R., Wölfel, V., Gleiter, R., Bischof, P., Friedrich, G.

Schwab, M., Sundermeyer, W.

Kuhn, N., Schumann, H.

Winter, M., Zauder, E.,

Evert7, K., Huttner, G.

Ziegler, M. L., Blechschmitt, K. Nuber, B.. Zahn, T.

Baudler, M., Becher, R.,

Germeshausen, J.

Elschenbroich, C., Schneider, J., Wünsch. M., Pierre. J.-L., Baret, P., Chautemps, P.

\section{Contents}

$\therefore, 0$

Properties of Tellurium-Tellurium Bonds. VI. - Structure and Barrier of Interconversion of Enantiomeric Conformations of Bis(2.4.6-tri-tert-butylphenyl)ditellane

Heterogeneous Photocatalysis. V. - Cadmium-Zinc Sulfides as Catalysts for the Photodehydrodimerization of 2,5-Dihydrofuran

Dchalogenation of Geminal Dihalocyclopropanes, $x, x$-Dichlorocyclobutanones, and Haloketones by Means of Magnesium Anthracene $\cdot 3 \mathrm{THF}$

New Magnesium Anthracene Complexes by Ligand Exchange

The Addition of Lithium Alkanides to Iminoboranes

Formation, Structure, and Reactions of Methyl(methylimino)borane

Bis(trifluoromethyl)sulfine, $\left(\mathrm{CF}_{3}\right)_{2} \mathrm{C}=\mathrm{SO}$ : Addition Reactions with Thiols, Amine $\mathrm{N}$ Oxides, Ethers, and 1,3-Dipoles

Synthesis and Reactivity of Dienylmetal Compounds, XXIX. - Protonation of $\mathrm{C}_{5} \mathrm{H}_{5} \mathrm{FeC}_{6} \mathrm{H}_{7}$ to Cyclohexadiene and Consequent Reactions

Regin- and Stcreoselectivity of Halogen Substitution in $\mathrm{Fc}_{2}(\mathrm{CO})_{6}(\mu-\mathrm{PRCl})(\mu-\mathrm{Hal})$

Synthesis and Characterization of $\left(\mathrm{C}_{5} \mathrm{H}_{5}\right)_{3}$ $\mathrm{M}_{3}(\mathrm{CO})_{6} \mathrm{As}$ and $\left(\mathrm{C}_{5} \mathrm{H}_{5}\right)_{2} \mathrm{M}_{2}(\mathrm{CO})_{4} \mathrm{As}_{2}$ and Derivatives of the Arsanetriyl Tetrahedrane

Contributions to the Chemistry of Phosphorus, 182. $-\mathrm{Li}_{2} \mathrm{P}_{26} \mathrm{R}_{2}$ and $\mathrm{LiP}_{26} \mathrm{R}_{3}$ $(\mathrm{R}=\mathrm{Me}, \mathrm{Et})$ - the First Partially Metalated Hexacosaphosphanes(4)

Metal $\pi$ Complexes of Benzene Derivatives, $X X X .-\eta^{6}-, \mu_{2}-\left(\eta^{6}: \eta^{6}\right)$-, and $\mu_{3-}$ $\left(\eta^{6}: \eta^{6}: \eta^{6}\right)-[2 ;]$ Paracyclophane Complexes of Chromium. Preparation, Nuclear Magnetic Resonance, and Redox Behavior

Forbidden Reactions. - $[2+2]$ Cycloreversion of Rigid Cyclobutanes
Breuckmann, R., Figge, L.

Lennart7, H.-W., Fessner, W.-D.,

Prinzbach, $\mathrm{H}$

Adam, W., Lupón, P.
1 Verbotene Reaktionen. - $[2+2]$-Cycloreversion starrer Cyclobutane
21 Die Chinolepoxide des $p$-Kresols und Östrons mittels Photooxygenierung und Titan(IV)- oder Vanadium(V)-katalysiertem Sauerstofftransfer
Quinol Epoxides from $p$-Cresol and Estrone by Photooxygenation and Titanium(IV)- or Vanadium(V)-Catalyzed Oxygen Transfer 


\section{Inhalt (Fortsetzung)}

Bogdanovic. B.. Schlichte, K., Westeppe. U.

Hcuschmann. M.

DAAnello. M., Erba. E.. Gelmi. M. L.. 67 Pocar. D.

Kreher. R. P.. Hildebrand. T.

81 Untersuchungen zur Chemic von Isoindolen und Isoindoleninen. XXVII. - 2Alkyl-2H-dibenz.[e,g]isoindole: Synthese. Eigenschaften, Reaktionen

Buss. V.. Klcin. M.

89 Berechnungen der elektronischen Struktur cines chiralen [2.2] Metacyclophans

Gotthardt. H., Böhm, F.-R.,

Brauer, D. J.. Weisshuhn. C. M. Wilke. C. J.

Liguori, A., Romeo, G..

Sindona. G.. Uccella. N.

95 Pyrrolo[1,2- $h]-1,3,4$-thiadiazol-Derivate aus mesomeren Heteropentalenen und Azodicarbonestern

105 N.O-Heterocyclen. 24. - Eine neue Untersuchung der Ringöffnung von Isoxazolidiniumsalzen zu 1.3-Aminoalkoholen

Effenberger, R., Steegmüller. D.

117 Racemisierungsfreic Eisen(III)chlorid-katalysicrte Acylierung von Aromaten mit $\mathrm{N}$ Phthaloyl-x-aminosäurechloriden

Effenberger, F., Stecgmüller. D..

125 Intramolckulare Friedel-Crafts-AcylieNull, V., Ziegler, T. rung von $N$-Phthaloyl-substituierten Arylund Homophenylalanylchloriden

Quast, H., Christ, J., Klaubert. C. A.. 131 Peters, E.-M., Peters. K., von Schncring, H. G.

Elschenbroich, C.. Schneider. J., Wünsch, M., Pierre. J.-L., Baret, P., Chautemps, P.

Ried, W., Reiher, U.

Drewello, T., Fessner, W.-D..

187 Vasphasenoxidation (..Charge-Stripping“) Kos, A. J., Lcbrilla, C. B. Prinzbac'n, H., von Ragué Schleyer, P., Schwarz. $\mathrm{H}$.

von der Brüggen, U.. Mayr. H.

177 Metall- $\pi-$ Komplexe von Benzolderivaten, $X X X .-\eta^{6}-, \quad \mu_{2}-\left(\eta^{6}: \eta^{6}\right)-$ und $\mu_{3}-\left(\eta^{6}:\right.$ $\left.\eta^{6}: \eta^{6}\right)-\left[2_{3}\right]$ Paracyclophan-Komplexe des Chroms. Darstcllung, kernmagnetische Resonanz. und Redoxverhalten

Diels-Alder-Reaktionen von 2,3-Bis(tertbutyldimethylsilyloxy)-1,3-butadien mit Heterodienophilen von ionisierten Pagodanen und verwandten Käfigkohlenwasserstoffen. - Eine theoretisch-experimentelle Studic zu Tetramethylen-Dikationen

Beitrag zur Verwendung von (Dichlormethyl)methylether als Formylierungsreagenz.

\footnotetext{
A I Richtlinien für Autoren

Publikationssprache
}

\section{Contents (Continued)}

Dehalogenation of Geminal Dihalocyclopropanes, $\alpha, \alpha$-Dichlorocyclobutanones, and Haloketones by Means of Magnesium Anthracene $\cdot 3 \mathrm{THF}$

Multi-Step Inverse Diels-Alder Reactions of 1,3-Dimcthyl-2-methylcneimidazolidine with Methyl 2,4-Hexadienoates

5-Oxazolones, II. - 2,4-Diaryl-4-(2,4-dinitroaryl)-5(4H)-oxazolones: Synthesis and Acid-Catalyzed Transformation into 1Hydroxy- $1 H$-indazole Derivatives

Studies on the Chemistry of Isoindoles and Isoindolenines, XXVII. - 2-Alkyl-2H-dibenz $[e, g]$ isoindoles; Synthesis. Properties, Reactions

Electronic Structure Calculations of a Chiral [2.2]Metacyclophane

Pyrrolo[1,2-b]-1,3,4-thiadiazole Derivatives from Mesomeric Heteropentalenes and Azodicarboxylic Esters

- N,O-Heterocycles, 24. - Novel Approach to the Ring-Opening Reaction of Isoxazolidinium Salts to 1,3-Amino Alcohols

Ferric Chloride-Catalyzed Acylation of Aromatic Compounds with $N$-Phthaloyl$\alpha$-amino Acyl Chlorides without Racemisation

Intramolecular Fricdel-Crafts Acylation of $N$-Phthaloyl-Substituted Arylalanyl and Homophenylalanyl Chlorides

Stereochemistry of the Hydrocyanation of 1.5-Dimethylbicyclo[3.3.0]octanones and -octenones

Metal $\pi$ Complexes of Benzenc Derivatives, XXX. - $\eta^{6}-, \mu_{2}-\left(\eta^{6}: \eta^{6}\right)$-, and $\mu_{3}$ $\left(\eta^{6}: \eta^{6}: \eta^{6}\right)-[2,3$ Paracyclophane Complexes of Chromium. Preparation, Nuclear Magnetic Resonance, and Redox Behavior

Diels-Alder Reactions of 2,3-Bis(tert-butyldimethylsilyloxy)-1,3-butadiene with Heterodienophiles

Gas-Phase Oxidation ("Charge Stripping") of Pagodane Radical Cations and Related Cage Hydrocarbons. - A Theoretical-Experimental Search into Tetramethylene Dications

Comment on the Use of Dichloromethyl Methyl Ether as Formylating Agent

- Instructions for Authors

- Language of Publication 


\title{
Comment on the Use of Dichloromethyl Methyl Ether as Formylating Agent
}

\author{
Uwe von der Brüggen and Herbert Mayr*
}

Institut für Chemie, Medizinische Universität zu Lübeck,

Ratzeburger Allee 160, D-2400 Lübeck 1, Federal Republic of Germany

Received August 27, 1987

In contrast to no rmal alkenes, dialkylacetylenes can be formylated with dichlo romethyl methyl ether (1) in the presence of 1.2 equivalents of boron trichloride. A rationalisation for the different behaviour of alkenes and alkynes arises from the NMR spectroscopic investigation of the reaction intermediates.

Dichloromethyl methyl ether (1) has been used for the formylation of aromatic co mpounds ${ }^{1)}$, but attempts to formylate isobutene $\mathbf{2 a}$ and trimethylethylene $\mathbf{2 b}$ gave only the 2:1 products $4^{2)}$. It has been concluded, therefore, that in electrophilic addition reactions to olefins the chloro ethers 3 are more reactive than $1^{2 a)}$.

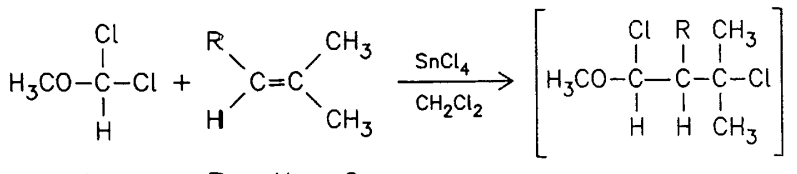

$$
\begin{aligned}
& 1 \quad \mathrm{R}=\mathrm{H} \quad 2 \mathrm{a} \\
& \mathbf{R}=\mathrm{CH}_{3} 2 \mathrm{~b}
\end{aligned}
$$

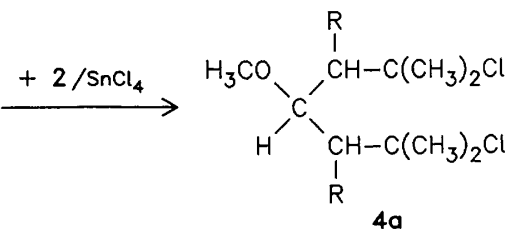

Analogously, the $1: 1$ products 6 , initially formed from 1 and ketene alkyltrimethylsilyl acetals $\mathbf{5}$, have been reported to react far faster than the starting ether $1^{3)}$. Only when both $R^{1}$ and $R^{2}$ were alkyl groups, steric hindrance reduced the rate of formation of $2: 1$ products, and $\alpha$-fformylcarboxylic esters, hydrolysis products of $\mathbf{6}$, were isolable in addition to 7.<smiles>[R]OC(O[Ga])=C([R1])[SH2+]</smiles><smiles>[R]OC(=O)C([R])([R])C(Cl)(OC)OCCCC</smiles><smiles>[R]OC([R20])C([R])([R])C([R])([R])C([R])([R])[R]</smiles>

We have demonstrated recently that the relative electrophilicity of alkyl chloridess depends on the degrec of ionisation. In predominantly unioniised systems the more readily ionised compound is found to be more reactive, while the opposite is true when the competing alkylating agents are ionised to a large extent ${ }^{4}$. On this basis, we have no'w analysed formylations with the dichloromethyl

methyl ether (1), though complications caused by anomeric stabilisation of 1 might be expected.

When compound 1 was treated with one or two equivalents of isobutene in the presence of 1.2 equivalents of $\mathrm{BCl}_{3}$, only the $2: 1$ product 4 a was obtained, in accord with previous reports ${ }^{2)}$. Under similar conditions, 1 and tetramethylethylene (2c) selectively gave the 1:1 product 8 after hydrolysis. Steric strain obviously inhibits the addition of $3 \mathrm{c}$ to a second alkene molecule.

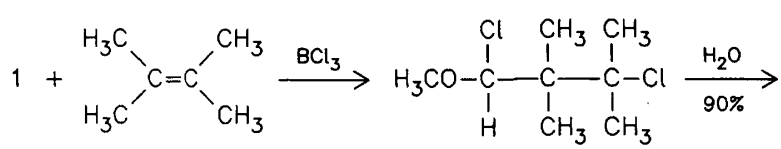

$2 c$

$3 c$<smiles>CC(C)(Cl)C(C)(C)C=O</smiles>

8

The termination of this addition at the stage of the $1: 1$ adduct $3 \mathrm{c}$ allows to analyse the degree of ionisation of the reactants 1 and the 1:1 products 3 . The NMR spectrum of a solution of 1 and 1.2 equivalents of $\mathrm{BCl}_{3}$ in $\mathrm{CD}_{2} \mathrm{Cl}_{2}$ showed that 1 is not ionised under these conditions. When compound $2 \mathrm{c}$ was added to this solution, the 'H-NMR spectrum showed singlets at $\delta=3.49\left(\mathrm{OCH}_{3}\right)$ and at $\delta=5.87(\mathrm{CH})$ as expected for unionised 3c. A fast exchange of $\mathrm{Cl}^{-}$is indicated by the observation that the diastereotopic methyl group signals at $\delta=0.94$ and 1.01 and at $\delta=1.46$ and 1.52 $\left(-100^{\circ} \mathrm{C}\right)$ became equivalent when the sample was warmed up to $-20^{\circ} \mathrm{C}$.

Since 3a, 3b can be expected to ionise to a similar degree as $\mathbf{3 c}$, the exclusive formation of $2: 1$ products - if strong steric effects are absent - can be explained on the basis of our general analysis: compounds 3 form better stabilised carbenium ions than $\mathbf{1}$ and are therefore more reactive in systems with a small degree of ionisation ${ }^{4.5}$. In principle, it should be possible to obtain $1: 1$ products by using stronger Lewis acids ${ }^{4}$. All attempts to formylate isobutenc with 1 have failed until now, and 2:1 products in addition to polymers were obtained when an excess of $\mathrm{TiCl}_{4}, \mathrm{SnCl}_{4}$, or $\mathrm{AlCl}_{3}$ was employed.<smiles>[R]/C=C\[SiH2]C</smiles>

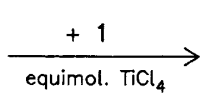

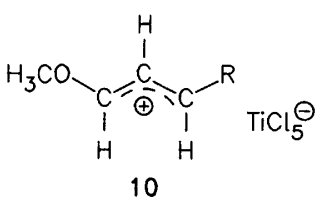<smiles>[R]/C=C\C=O</smiles> 
A different situation arises, when the $1: 1$ products give resonance-stabilised carbenium ions. It has been reported that vinylsilanes can be formylated by 1 in the presence of eimimolar amounts of $\mathrm{TiCl}_{4}{ }^{6}$ ), while allylsilanes give only $2: 1$ products under these conditions ${ }^{6 \mathrm{c})}$.

We interpret this finding by the low intrinsic reactivity of the cations 10 which are initially formed from 1 and vinylsilanes. Since similar types of $1: 1$ products may be formed by the addition of 1 to $\mathrm{CC}$ triple bonds, we investigated the formylation of alkynes under similar reaction conditions.

When the dialkylacetylenes $12 \mathbf{a}, \mathbf{b}$ were added to solutions of 1 and 1.2 equivalents of boron trichloride, the reactions terminate at the $1: 1$ product stage. Workup of the product obtained from 2butyne (12a) with methanol/potassium hydrogencarbonate gave a mixture of $14 \mathrm{a}$ and $15 \mathrm{a}$ which was converted into pure $15 \mathrm{a}$ by treatment with methyl orthoformate. Hydrolysis of the formylation product of 3-hexyne (12 b) was carried out with aqueous ammonium chloride solution to yield the stereoisomeric aldehydes $(E, Z)-\mathbf{1 4} \mathbf{b}$.
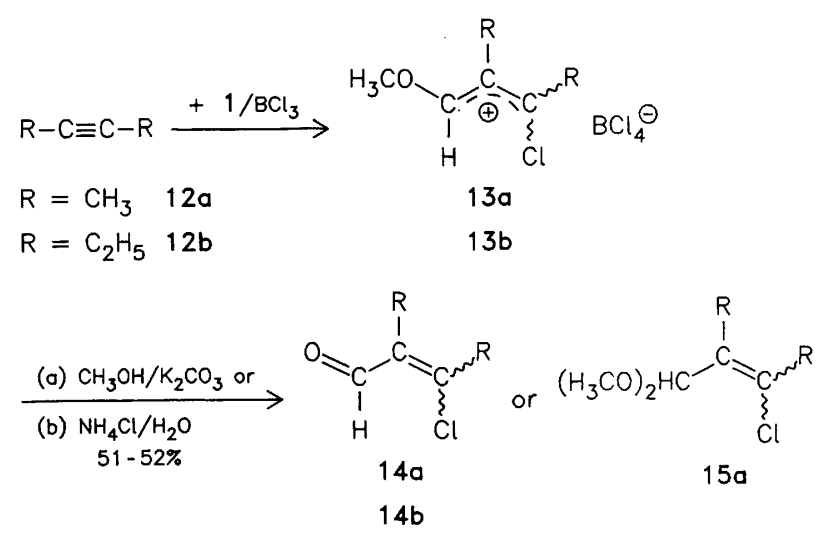

The ionic character of the intermediates 13 was proven by 'H= NMR spectroscopy. The spectrum taken after addition of 2-butyne to a mixture of 1 and $\mathrm{BCl}_{3}$ in $\mathrm{CD}_{2} \mathrm{Cl}_{2}$ showed methyl resonances at $\delta=2.04,2.80$, and 4.97 and a broad onc-proton singlet at $\delta=9.67$, as expected for 1-alkoxyallyl cations"). Additional signals at $\delta=1.34,2.24$, and $2.30(1: 1: 2)$ are close to those reported for the tetramethylcyclobutadiene aluminium chloride complex $(1.32,2.29,2.40)^{8)}$ and indicate that the $\mathrm{BCl}_{3}$-initiated dimerisation of 12a takes place as a side reaction. Lewis-acid-initiated oligomerisations of alkynes become dominant with terminal and aryl-substituted acetylenes, and attempts to formylate these types of compounds have not been successful.

Conclusion. Electrophilic formylations with dichloromethyl methyl ether (1) have previously been achieved with aromatic compounds and vinylsilanes and now with dialkylacetylenes. Since all these reactions require the use of at least 1 equivalent of strong Lewis acids and lead to the formation of intermediate delocalised carbenium ions of low intrinsic reactivity, it appcars that these two conditions are needed for the use of 1 as formylating agent, in accordance with theoretical considerations ${ }^{4}$. Until now, appropriate conditions for the formylation of ordinary alkenes (very strong Lewis acids would be needed) have not yet been found, and 1 could only be used for the electrophilic formylation of alkenes, when the electrophilic centre of the formylation product was sterically shielded.

We thank Ms. Roswitha Lammers for experimental assistance and the Deutsche Forschungsgemeinschaft for financial support.

\section{Experimental}

General: NMR: XL 200 (Varian), chemical shifts are recorded with respect to internal TMS. - Mass spectra: 70-250 (VG-Instruments). - IR: JR-435 (Shimadzu).

3-Chloro-2,2,3-trimethylbutanal (8): A $1 \mathrm{M}$ solution of $\mathrm{BCl}_{3}$ in $\mathrm{CH}_{2} \mathrm{Cl}_{2}(36 \mathrm{ml})$ was added to a solution of $1(3.45 \mathrm{~g}, 30.0 \mathrm{mmol})$ in $30 \mathrm{ml}$ of $\mathrm{CH}_{2} \mathrm{Cl}_{2}$ at $-78^{\circ} \mathrm{C}$. A solution of 2,3-dimethyl-2-butene (2c) $(5.40 \mathrm{~g}, 64.2 \mathrm{mmol})$ in $60 \mathrm{ml}$ of $\mathrm{CH}_{2} \mathrm{Cl}_{2}$ was added dropwise within $30 \mathrm{~min}$ and allowed to react for $3 \mathrm{~h}$ at $-78^{\circ} \mathrm{C}$. The mixture was washed with $100 \mathrm{ml}$ of $25 \%$ aqueous $\mathrm{NH}_{4} \mathrm{Cl}$ solution, the aqueous layer extracted with two $20-\mathrm{ml}$ portions of ether, and the combined organic layers were dried with $\mathrm{CaCl}_{2}$. Evaporation of the solvents gave $4.01 \mathrm{~g}(90 \%)$ of spectroscopically pure 8. - IR (neat): $2974 \mathrm{~cm}^{-1}, 1720,1458,1375,1155,1104,829 .{ }^{1} \mathrm{H} \mathrm{NMR}\left(\mathrm{CDCl}_{3}\right)$ : $\delta=1.21\left(\mathrm{~s}, 6 \mathrm{H}, 2-\mathrm{CH}_{3}\right), 1.63\left(\mathrm{~s}, 6 \mathrm{H}, 3-\mathrm{CH}_{3}\right), 9.83(\mathrm{~s}, 1 \mathrm{H}, 1-\mathrm{H})$. ${ }^{13} \mathrm{C} \mathrm{NMR}\left(\mathrm{CDCl}_{3}\right): \delta=18.95\left(\mathrm{q}, 2-\mathrm{CH}_{3}\right), 28.90\left(\mathrm{q}, 3-\mathrm{CH}_{3}\right) .52 .87$ (s, C-2), 73.68 (s, C-3), 204.41 (s, C-1). - 2,4-Dinitrophenylhydrazone of 8: M.p. $141-143^{\circ} \mathrm{C}$ (methanol). - MS $(70 \mathrm{eV}): m / z(\%)=$ 330 (3), $328(10)\left[\mathrm{M}^{+}\right], 252$ (39), 251 (100).

$$
\begin{array}{ll}
\mathrm{C}_{13} \mathrm{H}_{17} \mathrm{ClN}_{4} \mathrm{O}_{4} \text { (328.8) } & \text { Calcd. C } 47.50 \text { H } 5.21 \\
& \text { Found C } 47.62 \mathrm{H} 5.14
\end{array}
$$

Dichloromethyl Methyl Ether (1) and 2-Butyne (12a): A $1 \mathrm{M}$ solution of $\mathrm{BCl}_{3}$ in $\mathrm{CH}_{2} \mathrm{Cl}_{2}(36 \mathrm{ml})$ was added to a solution of $1(3.45 \mathrm{~g}$, $30.0 \mathrm{mmol}$ ) in $30 \mathrm{ml}$ of $\mathrm{CH}_{2} \mathrm{Cl}_{2}$ at $-78^{\circ} \mathrm{C}$. Compound $12 \mathrm{a}(1.62 \mathrm{~g}$, $30.0 \mathrm{mmol}$ ), dissolved in $60 \mathrm{ml}$ of $\mathrm{CH}_{2} \mathrm{Cl}_{2}$, was added with stirring within $1 \mathrm{~h}$ to give a slightly yellow solution which became turbid $30 \mathrm{~min}$ after completion of the addition. After $2 \mathrm{~h}, 25.0 \mathrm{~g}$ of $\mathrm{K}_{2} \mathrm{CO}_{3}$ and $10 \mathrm{ml}$ of anhydrous methanol were added, and stirring at $-78^{\circ} \mathrm{C}$ was continued for another $15 \mathrm{~min}$. The mixture was warmed at ambient temperature and washed with $30 \mathrm{ml}$ of concentrated aqueous ammonia. The aqueous layer was extracted with two $20-$ $\mathrm{ml}$ portions of ether, the combined organic layers were dried with $\mathrm{Na}_{2} \mathrm{SO}_{4}$, and the solvent was evaporated to give a mixture of $(E, Z)$ 14a and (E,Z)-15a. Complete acetalisation of 14a was achieved by stirring this mixture with methanol $(0.96 \mathrm{~g}, 30.0 \mathrm{mmol})$, methyl orthoformate $(3.18 \mathrm{~g}, 30.0 \mathrm{mmol})$, and $\mathrm{NH}_{4} \mathrm{NO}_{3}(0.2 \mathrm{~g})$ for $14 \mathrm{~h}$. After alkalisation with diisopropylamine, $30 \mathrm{ml}$ of ether was added. The mixture was filtered and distilled $\left(64-66^{\circ} \mathrm{C} / 25 \mathrm{mbar}\right)$ to give $2.58 \mathrm{~g}(52 \%)$ of $15 \mathrm{a}(2: 1$ mixture of stereoisomers).

(E,Z)-3-Chloro-1,1-dimethoxy-2-methyl-2-butene (15a): ${ }^{1} \mathrm{H}$ NMR $\left(\mathrm{CDCl}_{3}\right)$, major isomer: $\delta=1.71\left(\mathrm{~m}_{\mathrm{c}}, 3 \mathrm{H}, 2-\mathrm{CH}_{3}\right), 2.14\left(\mathrm{~m}_{\mathrm{c}}, 3 \mathrm{H}\right.$, 4-H), $3.39\left(\mathrm{~s}, 6 \mathrm{H}, \mathrm{OCH}_{3}\right), 5.27(\mathrm{~s}, 1 \mathrm{H}, 1-\mathrm{H})$; minor isomer: $\delta=1.80$ $\left(\mathrm{m}_{\mathrm{c}}, 3 \mathrm{H}, 2-\mathrm{CH}_{3}\right), 2.21\left(\mathrm{~m}_{\mathrm{c}}, 3 \mathrm{H}, 4-\mathrm{H}\right), 3.34\left(\mathrm{~s}, 6 \mathrm{H}, \mathrm{OCH}_{3}\right), 4.93(\mathrm{~s}$, $1 \mathrm{H}, 1-\mathrm{H}) .-{ }^{13} \mathrm{C} \mathrm{NMR}\left(\mathrm{CDCl}_{3}\right)$, major isomer: $\delta=12.19(\mathrm{q}, 2-$ $\mathrm{CH}_{3}$ ), 22.23 (q, C-4, possibly other isomer), 54.90 (q, $\mathrm{OCH}_{3}$ ), 103.91 (d, C-1), 128.76 (s, C-2), 130.96 (s, C-3); minor isomer: $\delta=14.01$ (q, 2- $\mathrm{CH}_{3}$ ), 22.78 (q, C-4, possibly other isomer), $54.17\left(\mathrm{q}, \mathrm{OCH}_{3}\right), 102.8$ (d, C-1), 128.1 (s, C-2), 129.7 (s, C-3). - MS (70 eV): $m / z(\%)=$ $166(0.23), 164(0.73)\left[\mathrm{M}^{+}\right], 135(18), 133(57), 129(18), 97$ (10), 75 (58), $31(100)$.

$$
\begin{array}{ll}
\mathrm{C}_{7} \mathrm{H}_{13} \mathrm{ClO}_{2} \text { (164.6) } & \text { Calcd. C 51.07 H } 7.96 \\
& \text { Found C } 51.67 \mathrm{H} 7.81
\end{array}
$$

Dichloromethyl Methyl Ether (1) and 3-Hexyne (12b): A $1 \mathrm{M}$ solution of $\mathrm{BCl}_{3}$ in $\mathrm{CH}_{2} \mathrm{Cl}_{2}(36 \mathrm{ml})$ was added to a precooled solution $\left(-78^{\circ} \mathrm{C}\right)$ of $1(3.45 \mathrm{~g}, 30.0 \mathrm{mmol})$ in $30 \mathrm{ml}$ of $\mathrm{CH}_{2} \mathrm{Cl}_{2}$. A solution of $12 \mathrm{~b}(2.46 \mathrm{~g}, 30.0 \mathrm{mmol})$ in $60 \mathrm{ml}$ of $\mathrm{CH}_{2} \mathrm{Cl}_{2}$ was added within 30 min and stirred for $2 \mathrm{~h}$ at $-78 \mathrm{C}$. The mixture was poured onto $200 \mathrm{ml}$ of aqueous $\mathrm{NH}_{4} \mathrm{Cl}$ solution $(25 \%)$, the aqueous layer was washed with two 30 -ml portions of $\mathrm{CH}_{2} \mathrm{Cl}_{2}$, and the combined organic layers were dried with $\mathrm{CaCl}_{2}$. Distillation at $65-80^{\circ} \mathrm{C}$ (bath)/32 mbar gave $2.24 \mathrm{~g}(51 \%)$ of (E,Z)-3-chloro-2-ethyl-2-pen- 
tenal (14b) $(\approx 2: 1$ mixture of stereoisomers) contaminated with small amounts $(\approx 10 \%)$ of an unknown impurity. -- Mixture of $(E, Z)-14 b:$ IR (neat): $1676 \mathrm{~cm}^{-1}, 1609,-{ }^{1} \mathrm{H}$ NMR $\left(\mathrm{CDCl}_{3}\right): \delta=$ $0.98\left(\mathrm{t}, J=7.5 \mathrm{~Hz}, \mathrm{CH}_{3}\right), 1.26$ and $1.29\left(2 \mathrm{t}, J=7.4 \mathrm{~Hz}, \mathrm{CH}_{3}\right)$, 2.34, 2.44, 2.64, 2.93 (4 q, $\left.J=7.5 \mathrm{~Hz}, \mathrm{CH}_{2}\right), 10.01,10.21$ (2 s, ratio $2: 1, \mathrm{CH}=\mathrm{O}) .-{ }^{13} \mathrm{C} \mathrm{NMR}\left(\mathrm{CDCl}_{3}\right): \delta=11.93,11.98,13.47(3 \mathrm{q}$, $\mathrm{CH}_{3}$ ), 19.47, 20.48 (2 t), 28.24, 30.59 (2 t), 139.40 (s, C-2), 154.82, 159.20 ( 2 s, C-3, assignment uncertain), 186.94, 191.21 (2 d, CHO). MS $(70 \mathrm{eV}): m / z(\%)=148(32), 146(100)\left[\mathrm{M}^{+}\right], 133(3), 131(8)$, 119 (9), 117 (24), 111 (37), 95 (36), 93 (17), 89 (20), 81 (36), 67 (76).

When the crude reaction product obtained from $30 \mathrm{mmol}$ of 1 and $12 \mathrm{~b}$ was not distilled but treated with 2,4dinitrophenylhydrazine ${ }^{9)}$, a mixture of stereoisomeric 2,4-dinitrophenylhydrazones $(5.00 \mathrm{~g}, 51 \%)$ was obtained, which was separated by MPLC $(30 \times 2.5 \mathrm{~cm}$ LiChroprep $\mathrm{Si} 60.15-25 \mu$, hexane: $\mathrm{CH}_{2} \mathrm{Cl}_{2}=5: 1,12.5 \mathrm{ml} / \mathrm{min}$ ) to give $2.47 \mathrm{~g}$ of an isomer I with $R_{\mathrm{t}}=8.7 \mathrm{~min}$ and $0.89 \mathrm{~g}$ of an isomer II with $R_{\mathrm{t}}=9.7 \mathrm{~min}$. - 2,4-Dinitrophenylhydrazone of $14 \mathrm{~b}$ (isomer l): M.p. $147-148^{\circ} \mathrm{C}$ (hexane/ $\left.\mathrm{CH}_{2} \mathrm{Cl}_{2}\right)$. - ${ }^{\mathrm{t}} \mathrm{H}$ NMR $\left(\mathrm{CDCl}_{3}\right): \delta=1.14(\mathrm{t}, J=7.5 \mathrm{~Hz}$, $\left.3 \mathrm{H}, \mathrm{CH}_{3}\right), 1.24\left(\mathrm{t}, J=7.4 \mathrm{~Hz}, 3 \mathrm{H}, \mathrm{CH}_{3}\right), 2.60(\mathrm{q}, J=7.5 \mathrm{~Hz}, 2 \mathrm{H}$, $\mathrm{CH}_{2}$ ), 2.63 (q, $J=7.4 \mathrm{~Hz}, 2 \mathrm{H}, \mathrm{CH}_{2}$ ), 11.26 (br. s, $1 \mathrm{H}, \mathrm{NH}$ ), aryl $\mathrm{H}$ as usual. $-{ }^{13} \mathrm{C} \mathrm{NMR}\left(\mathrm{CDCl}_{3}\right): \delta=12.63(\mathrm{q}), 13.90(\mathrm{q}), 21.51(\mathrm{t})$, $29.91(\mathrm{t}), 116.6$ (d), 123.5 (d), 129.4 (s), 130.0 (d), 132.3 (s), 138.2 (s), 144.3 (s), 144.8 (s), 147.2 (d).

$$
\mathrm{C}_{13} \mathrm{H}_{15} \mathrm{ClN}_{4} \mathrm{O}_{4} \text { (326.7) Calcd. C } 47.79 \mathrm{H} 4.63
$$

Found C 47.91 H 4.68

2,4-Dinitrophenylhydrazone of $\mathbf{1 4 b}$ (isomer II): M.p. $154-156^{\circ} \mathrm{C}$ (hexane $\left./ \mathrm{CH}_{2} \mathrm{Cl}_{2}\right)$. $-{ }^{1} \mathrm{H}$ NMR $\left(\mathrm{CDCl}_{3}\right): \delta=1.13(\mathrm{t}, J=7.5 \mathrm{~Hz}$, $\left.3 \mathrm{H}, \mathrm{CH}_{3}, .5 \mid J=7.5 \mathrm{~Hz}, 3 \mathrm{H}, \mathrm{CH}_{3}\right), 2.70(\mathrm{q}, J=7.5 \mathrm{~Hz}, 4 \mathrm{H}$, $\left.\left.2 \mathrm{CH}_{2}\right), 114 \mathrm{H} ; \mathrm{H}, \mathrm{NH}\right)$, aryl $\mathrm{H}$ as usual. $-{ }^{13} \mathrm{C} \mathrm{NMR}\left(\mathrm{CDCl}_{3}\right)$ : 12.41 (q), 13.47 a) 22.65 (t), 29.03 (t), 116.7 (d), 123.5 (d), 129.3 (s), 130.1 (d), 133.8 is) $138.2(\mathrm{~s}), 144.5$ (d), $144.8(\mathrm{~s}), 146.1$ (s).

1) (a) A. Rieche. H. Gross, E. Höft, Chem. Ber. 93 (1960) 88 . (b) H. Gross, A. Rieche, G. Matthey, Chem. Ber. 96 (1963) 308.

${ }^{2}{ }_{2 a}$ C. F. Garbers, H. S. C. Spies, H. E. Visagie, J. C. A. Boeyens, A. A. Chalmers. Tetrahedron Lett. (1978) 81. - ${ }^{26)}$ C. Duschek B. Drews, M. Muehlstaedt Ger. (East) 115, 650 (Cl. CO7 C43/12) (12. Oct. 1975) [Chem. Abstr. 87 (1977) 5391 j].

3) S. Tanimoto, T. Kokubo, T. Oida, H. Ikehira, Synthesis 1982 , 723.

${ }^{4)}$ H. Mayr. C. Schade, M. Rubow, R. Schneider, Angew. Chem. 99 (1987) 1059; Angew. Chem. Int. Ed. Engl. 26 (1987) 1029.

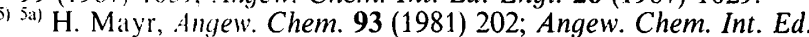
Engl. 20 (1981) 184. - ${ }^{5 b)}$ H. Mayr, W. Striepe, J. Org. Chem. 48 (1983) 1159

6) 6a! K. Yamamoto, O. Nunokawa, J. Tsuji, Synthesis 1977, 721. - ${ }^{6 b)}$ T. H. Chan, P. W. K. Lau, W. Mychajlowskij, Tetrahedron Lett. 1977, 3317. - ${ }^{6 c)}$ K. Yamamoto, J. Yoshitake, N. T. Qui, J. Tsuji, Chem. Lett. 1978, 859. - ${ }^{6 d)}$ K. Yamamoto, M. Ohta, J. Tsuji, Chem. Lett. 1979, 713.

${ }^{7)}$ G. A. Olah. Y. Halpern, Y. K. Mo, G. Liang, J. Am. Chem. Soc. 94 (1972) 3554

${ }^{8)}$ H. Hogeveen, H. Jorritsma, P. A. Wade, Tetrahedron Lett. 1974, 3915.

") Organikum, Organisch-Chemisches Grundpraktikum, $15^{\text {th }}$ edition, p. 484, VEB Deutscher Verlag der Wissenschaften, Berlin 1977.

$[236 / 87]$ 